\title{
Menurunkan Biomarker Migren Secara Cepat dengan Terapi “Assisted Drainage” (Studi Eksperimental pada Hewan coba)
}

\section{Haryono Utomo}

Klinik Spesialis Terpadu Rumas Sakit Gigi dan Mulut Fakultas Kedokteran Gigi Universitas Airlangga, Surabaya, Jawa Timur, Indonesia JI Prof. Dr. Moestopo 47. Surabaya, Jawa Timur, Indonesia; e-mail: dhoetomo@indo.net.id

\begin{abstract}
ABSTRAK
Migren merupakan gejala nyeri kepala rekuren yang paling sering dikeluhkan dalam dunia medis. Di Amerika Serikat, lebih dari 30 juta orang menderita satu atau lebih nyeri kepala migren dalam setahun. Berdasarkan literatur, migren merupakan komorbiditas rinosinusitis dan asma serta melibatkan saraf trigeminus. Tatalaksana migren dalam bidang kedokteran adalah obat-obatan dan tindakan invasif seperti injeksi atau operasi pada saraf. Sangat menarik bahwa menurut laporan kasus telah dibuktikan bahwa migren berhubungan dengan gingivitis karena suatu perawatan periodontal non invasif yang disebut sebagai terapi "assisted drainage" (ADT) dapat mengurangi gejala migren dalam hitungan menit. Terapi tersebut berupa masase sulkus gingiva dalam 3 menit dengan sisi tumpul scaler manual sampai timbul keluarnya darah secara pasif. Akan tetapi mekanisme kejadian pengurangan gejala migren setelah ADT masih belum jelas. Tujuan penelitian adalah untuk verifikasi pengaruh ADT terhadap penurunan biomarker migren tikus nonalergi dan alergi yang gingivitis. Tikus Wistar dibagi menjadi dua kelompok secara acak, penelitian dengan control series design study. Kelompok perlakuan adalah tikus alergi yang diinduksi dengan ovalbumin (OVA) dan non-alergi, kelompok ini disuntik dengan lipopolisakarida Porphyromonas gingivalis. Kelompok kontrol positif adalah tikus alergi, kontrol negatif dengan phosphate buffered saline (PBS). Pada beberapa kelompok dilakukan ADT. Ekspresi substans $\mathrm{P}$ (SP), leukotrien C4 (LTC4) dan TNF a pada gingiva dan hidung diperiksa dengan imunohistokimia peroksidase. Analisis statistik dengan ANOVA. ADT menurunkan ekspresi SP, LTC4 dan TNF $\alpha$ dengan sangat bermakna $(p<0.05)$ setelah 30 menit dilakukan ADT. Kesimpulan yang didapatkan dalam riset ini adalah ADT dapat mengurangi biomarker migren dalam hitungan menit sehingga dapat diusulkan sebagai terapi ajuvan dalam tatalaksana migren.
\end{abstract}

Maj Ked Gi Ind. Juni 2015; 1(1): hal 38-46

Kata kunci: tatalaksana migren, asma alergi, terapi "assisted drainage", tikus Wistar

ABSTRACT: Rapid Decrease in Migraine Biomarkers with Assisted Drainage Therapy (Experimental Study In Animal model). Migraine is a recurrent headache symptom which is most often suffered in medical community. In the USA, more than 30 million people suffered one or more migraine headaches in one year. According to literature, migraine has comorbidity with rhinosinusitis and asthma involving the trigeminal nerve. Migraine management in medicine is drugs as well as invasive procedures such as trigeminal nerve injection and surgery. Interestingly, case reports revealed that migraine is also connected with gingivitis since a non-invasive periodontal treatment so called "assisted drainage" therapy (ADT) is able to reduce migraine within minutes. It is a gingival sulcus massage for 3 minutes using the blunt side of manual sickle scaler until blood oozes passively. Nevertheless, the mechanism for how ADT reduces migraine is still unclear. The objective of the research is to verify the mechanism for how ADT decreases migraine biomarkers in non-allergic and allergic rats with gingivitis. Two groups of Wistar rats were randomly selected with control series design study. The treament groups were ovalbumin-induced allergic rats and non-allergic rats injected with Porphyromonas gingivalis lipopolysaccharides. The control groups were allergic rats as positive control, and negative control injected with phospate buffered saline (PBS). In several groups, ADT was conducted. Substance P (SP), leukotriene C4 (LTC4) and TNFa expressions in gingiva and nose were examined with peroxidase immuohistochemistry. The statistical analysis was conducted with ANOVA. ADT significantly decreased SP, LTC4 and TNF- $\alpha$ expressions $(p<0.05)$. ADT was able to decrease migraine biomarkers within minutes, therefore it can be proposed as an ajuvant in migraine management. Maj Ked Gi Ind. Juni 2015; 1(1): hal 38-46

Keywords: migraine management, allergic asthma, assisted drainage therapy, wistar rats

\section{PENDAHULUAN}

Migren adalah nyeri kepala neurovaskuler kambuhan yang ditandai dengan nyeri kepala berdenyut parah berkala, disertai mual, muntah, fotofobia, fonofobia, enggan melakukan aktivitas fisik. Prevalensi migren meningkat dari $4 \%$ sebelum pubertas sampai pada puncaknya, yaitu $25 \%$ pada wanita usia subur serta berkurang setelah menopause. Kurang lebih 30 juta penduduk Amerika Serikat dewasa (18\% wanita dan $6 \%$ of pria) menderita migren. ${ }^{1}$ 
Hubungan migren dengan alergi telah banyak diteliti. Penelitian terkini menemukan bahwa migren 1,5 kali lebih sering terjadi pada penderita alergi (asma, rinosinusitis alergi dan bronkitis kronik). Berdasarkan hubungan ini, diperkirakan bahwa keradangan di mukosa hidung dan sinus penderita rinosinusitis alergi dapat menjadi pemicu migren yang potensial karena mempunyai persarafan yang sama, yaitu nervus trigeminus. ${ }^{2}$ Penelitian klinis maupun epidemiologis, walau tidak seluruhnya, menyatakan keberadaan hubungan antara migren dan asma. Tahun 1977, beberapa peneliti menyebut asma sebagai migren paru (pulmonary migraine atau acephalgic migraine) ${ }^{1}$

Berbagai gejala penyakit seperti nyeri haid, nyeri kepala akibat migren dan nyeri otot ${ }^{3,4}$ telah berhasil dikurangi setelah perawatan periodontal yaitu pembersihan karang gigi dan kuretase, akan tetapi perawatan perlu dilakukan secara menyeluruh dalam rongga mulut. Keistimewaan terapi assisted drainage (ADT) untuk gejala penyakit seperti sinusitis ${ }^{5}$ dan asma ${ }^{6}$ adalah cukup dilakukan pada rahang atas saja pada lokasi tertentu dan efek perbaikan sudah terasa dalam hitungan menit. Terapi ini merupakan perawatan periodontal berupa masase sulkus gingiva selama tiga menit menggunakan bagian tumpul punggung scaler bentuk bulan sabit. Masase dilakukan selama kurang lebih 3 menit sampai terjadi pengeluaran darah secara pasif (drainase). Penelitian Utomo dan Harsono $^{6}$ melaporkan kejadian penurunan bermakna kadar histamin serum anak asma alergi dua jam setelah dilakukan ADT. Walaupun demikian, mekanisme kejadian penurunan gejala migren setelah dilakukan ADT di sulkus gingiva geraham rahang atas masih belum jelas.

Dr Meggs $^{7}$ pada tahun 1997 mengajukan hipotesa penjalaran lokal dapat menimbulkan keradangan di organ lain yang disebut neurogenic switching hypothesis. Konsep tersebut memperkirakan ada interaksi antara keradangan imunogenik yang diperantarai produk sel mast dengan keradangan neurogenik yang diperantarai produk saraf aferen sensoris maupun autonom sehingga terjadi peningkatan keradangan setempat. Peningkatan keradangan setempat tersebut lambat laun meningkatkan impuls antidromik ke sistem saraf pusat, kemudian SSP akan meneruskan impuls secara prodromik ke saraf eferen organ lain. Lundy dan Linden ${ }^{8}$ membahas lebih dalam konsep interaksi keradangan tersebut yang dapat terjadi di dalam rongga mulut. Hipotesa tersebut sudah banyak dibuktikan sehingga dianggap sebagai mekanisme yang telah mapan, ${ }^{9}$ sehingga dapat menerangkan penjalaran gingivitis ke jaringan lain dan menjelaskan pengaruh ADT terhadap biomarker migren. Biomarker yang terlibat dalam neurogenic switching dan juga migren adalah TNF- $\alpha$, merupakan produk berbagai sel imun, penyebab nyeri dan juga dapat merangsang ujung saraf aferen, ${ }^{2}$ leukotrien C4 (LTC4) yang menunjukkan aktivitas sel mast dan penyebab nyeri, ${ }^{10}$ serta substans $\mathrm{P}(\mathrm{SP})$ yang selain menunjukkan aktivitas sel saraf juga dapat merangsang degranulasi sel mast. ${ }^{8}$

Hewan coba model migren yang ideal sampai saat ini belum didapatkan untuk mengevaluasi hasil terapi pada manusia. Keberhasilan pada hewan ternyata gagal pada uji coba klinis karena perbedaan dalam bahan pemicu, modulasi cortical spreading depression (CSD); ataupun tidak tepat sasaran obat pada kompleks trigeminovaskuler. ${ }^{11}$ Karena tujuan utama penelitian ini untuk verifikasi hasil terapi klinis, maka dicari model hewan coba yang: (1) telah mapan untuk penelitian klinis manusia, paling mendekati patogenesa migren; (2) dapat untuk memeriksa interaksi keradangan imunogenik dan neurogenik; dan (3) melibatkan nervus trigeminus, yaitu model sinusitis dan asma alergi, ${ }^{12}$ selain itu karena kedua penyakit ini juga merupakan komorbiditas dari migren..$^{1,2}$

Untuk membuktikan bahwa keradangan pada gingivitis dapat menjalar kejaringan lain (a.l. hidung), karena sinusitis terlibat dalam patogenesa migren, ${ }^{13}$ serta pengaruh ADT terhadap migren, dilakukan percobaan pada tikus Wistar yang gingivitis dan kemudian dilakukan ADT. Tikus wistar jantan dibagi menjadi dua kelompok non-alergi dan alergi yang dimodelkan gingivitis. Perlakuan gingivitis adalah dengan suntikan intrasulkuler lipopolisakarida Porphyromonas gingivalis dengan mass ion 1435 dan $1450 \mathrm{PgLPS}_{1435 / 1450}$ dosis rendah $(<1,0 \mu \mathrm{g} / \mathrm{mL})$ dan tinggi $(\geq 1.0 \mu \mathrm{g} / \mathrm{mL}) ; 14,15$ kontrol disuntik dengan 
phosphate buffered saline (PBS). Sebagian tikus dibuat menjadi alergi, 15 dengan perlakuan suntikan Ovalbumin (OVA) intraperitoneal. ${ }^{15}$ Sebagai pemicu reaksi akut yang sama sebelum dilakukan ADT, dilakukan inhalasi OVA. Setelah euthanasia jaringan gingiva dan hidung dipotong dan dilakukan pemeriksaan munohistokimia peroksidase dengan diamino benzidin (DAB). Tujuan penelitian ini adalah untuk verifikasi pengaruh ADT terhadap penurunan biomarker migren tikus non-alergi dan alergi yang gingivitis.
Terapi assisted drainage yaitu masase pada sulkus gingiva tikus dengan bagian tumpul di punggung scaler bentuk bulan sabit selama 3 menit (Gambar 2 dan 3), lokasi diantara dua molar atas dilakukan 30 menit sebelum inhalasi OVA. Dalam penelitian ini ADT dilakukan pada tikus Wistar non-alergi yang diinjeksi $P g$ LPS $_{1435 / 450}$ serta alergi yang diinjeksi $P g$ LPS $_{1435 / 1450}$ sebelum inhalasi OVA (hari ke 4 pada non alergi dan hari ke 21 pada alergi). Modulasi biomarker migren serta mekanisme neurogenic switching diharapkan dapat

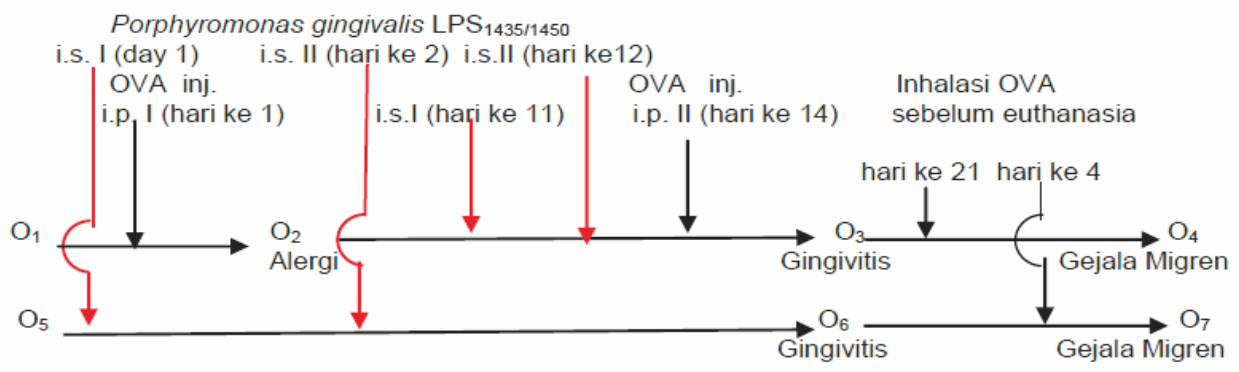

Gambar 1. Rancangan penelitian control series study, injeksi LPS $_{1435}$ Porphyromonas gingivalis Notes:

$\left(P g L_{P S} S_{1435 / 1450}\right)$ intrasulkuler tikus non-alergi dan alergi dengan induksi OVA intraperitoneal

$\mathrm{O}_{1}$ tikus yang akan diinduksi alergi dengan Ovalbum intraperitoneal (i.p)

$\mathrm{O}_{2}$ tikus alergi

$\mathrm{O}_{3}$ tikus alergi dan gingivitis

$\mathrm{O}_{4}$ tikus alergi dan gingivitis yang telah diinhalasi OVA

$\mathrm{O}_{5}$ tikus non-alergi yang akan diinjeksi $P g \mathrm{LPS}_{1435 / 1450}$ intrasulkular (i.s.)

$\mathrm{O}_{6}$ tikus non-alergi gingivitis yang akan diinhalasi OVA

$\mathrm{O}_{7}$ tikus non-alergi gingivitis yang telah diinhalasi OVA

\section{METODE PENELITIAN}

Pada penelitian factorial design, tikus Wistar jantan (120-150 gram) dibagi secara acak menjadi 2 kelompok perlakuan, kelompok tikus non-alergi yang disuntik dengan intrasulkuler (i.s) PgLPS $_{1435 / 1450}$ (Astarte Biol., USA) (K1 $0.3 \mu \mathrm{g} / \mathrm{mL}$ dan $\mathrm{K} 23,0 \mu \mathrm{g} / \mathrm{mL}$ ) dan tikus alergi yang disuntik dengan $P g \mathrm{LPS}_{1435 / 450}(\mathrm{~K} 30.3 \mu \mathrm{g} / \mathrm{mL}$ dan $\mathrm{K} 43,0 \mu \mathrm{g} /$ $\mathrm{mL}$ ) serta satu kelompok kontrol $\mathrm{K} 5$ yang disuntik dengan PBS, per kelompok 6 tikus. Untuk induksi alergi digunakan metode Toward dan Brodley, ${ }^{16}$ pada hari pertama dan ke 14 tikus Wistar disuntik i.p. OVA $10 \mu \mathrm{g}$ dalam $100 \mathrm{mg} \mathrm{AIOH}$ sampai volume $1 \mathrm{~mL}$ dosis $200 \mu \mathrm{L}$ i.p. Hari ke 21 dilakukan inhalasi OVA $1 \mathrm{mg} / \mathrm{mL}$ dalam saline steril, dosis $1 \mathrm{ml}$ inh. selama 30 menit. Penyuntikan i.s. PgLPS ${ }_{1435 / 1450} 0.3$ dan $3.0 \mu \mathrm{g} / \mathrm{mL}$ pada tikus non-alergi pada hari 1 dan ke 2 , sedangkan pada tikus alergi pada hari ke 11 dan 12 (Gambar 1). menerangkan efek imunoneuromodulasi ADT dan perbaikan gejala migren secara cepat.

Protokol penelitian telah lolos uji etik pada Animal Care and Use Ethical Committee Fakultas Kedokteran Hewan Universitas Airlangga. Analisis statistik dilakukan dengan uji ANOVA untuk mengetahui interaksi antara OVA, dosis PgLPS $_{1435 / 1450}$ dan ADT. Pemeriksaan jaringan dilakukan pada hari 4 pada tikus non-alergi; hari ke 14 (sensitisasi OVA i.p. kedua) dan hari ke 21 (sebelum dan sesudah inhalasi OVA) pada tikus alergi. Pada tiap tahap perlakuan dilakukan euthanasia untuk mendapatkan sampel gingiva dan hidung yang baik. Monoklonal antibodi yang digunakan; Substans P (Santa Cruz Biotechnology, Inc., Amerika; nomor catalog SP: sc-58591); LTC4 jaringan (US-Biological, Amerika; nomor katalog L-2047) dan TNF- $\alpha$ (Santa Cruz Biotechnology, Inc., Amerika; nomor katalog TNF: sc-31351). 

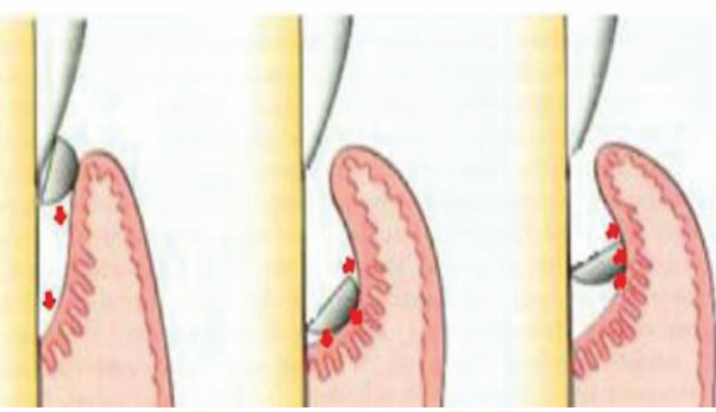

Gambar 2. Terapi "assisted drainage"masase sulkus gingiva (panah merah) dengan punggung scaler bulan sabit (adaptasi dari Newmann dkk, 2010) ${ }^{17}$

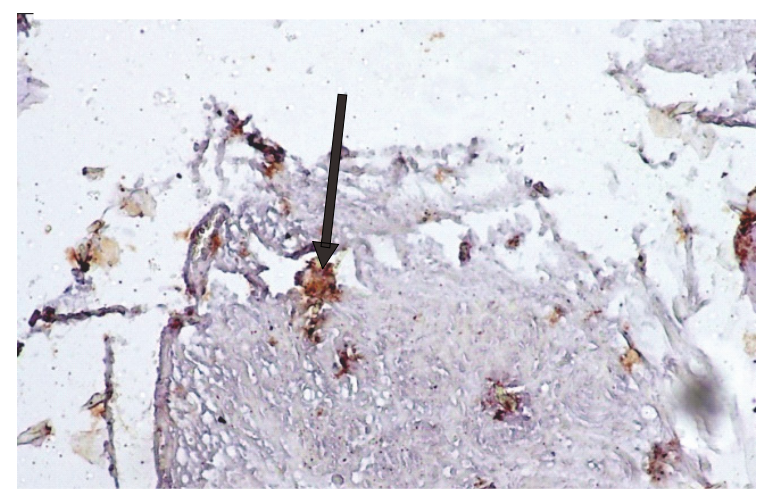

Gambar 4. Ekspresi Substans P gingiva sebelum injeksi PgLPS dan Ovalbumin (panah).

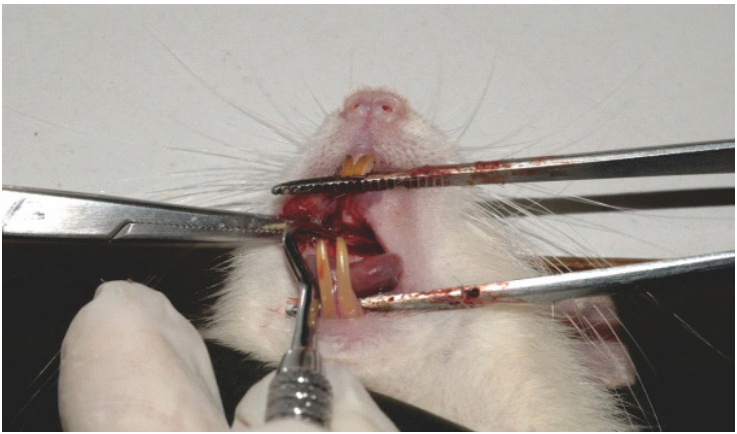

Gambar 3. Terapi "assisted drainage" pada tikus

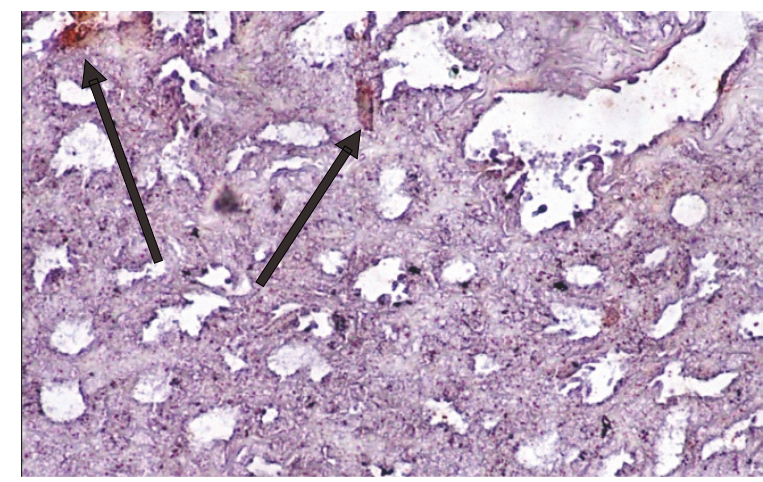

Gambar 5. Ekspresi Substans P gingiva setelah penyutikan $P g$ LPS ke 2 sebelum penyuntikan Ova ke 2 hari ke 14 Perbesaran 400x

\section{HASIL PENELITIAN}

Pada hasil penelitian ini yang ditampilkan adalah ekpresi variabel pada jaringan gingiva sebagai tempat stimulasi ADT dan hidung sebagai organ sasaran.

\section{Analisis Varians (ANOVA)}

\begin{tabular}{|c|c|c|c|c|c|c|}
\hline \multirow{2}{*}{$\begin{array}{l}\text { Variabel } \\
\text { Tergantung } \\
\text { Keradangan: } \\
\text { Imunogenik }\end{array}$} & \multirow{2}{*}{$\begin{array}{l}\text { Pra-inhalasi } \\
\text { Rerata } \pm \text { SD }\end{array}$} & \multicolumn{2}{|c|}{$\begin{array}{l}\text { inhalasi OVA } \\
\text { tanpa ADT }\end{array}$} & \multicolumn{2}{|c|}{$\begin{array}{l}\text { inhalasi OVA } \\
\text { Dengan ADT }\end{array}$} & \multirow{2}{*}{$\begin{array}{c}\text { Tanpa ADT vs. } \\
\text { dengan ADT } \\
p\end{array}$} \\
\hline & & Rerata \pm SD & $\mathrm{p}$ & Rerata \pm SD & $\mathbf{P}$ & \\
\hline $\begin{array}{l}\text { TNF- } \alpha \\
\text { LTC4 } \\
\text { Neurogenik }\end{array}$ & $\begin{array}{c}29.833 \pm 1.169 \\
3.50 \pm 0.548\end{array}$ & $\begin{array}{l}21.667 \pm 1.966 \\
20.50 \pm 0.548\end{array}$ & $\begin{array}{l}.001 \\
.001\end{array}$ & $\begin{array}{c}24.333 \pm 2.805 \\
13.833 \pm 1.602\end{array}$ & $\begin{array}{l}.001 \\
.001\end{array}$ & $\begin{array}{l}.001 \\
.001\end{array}$ \\
\hline Substans P & $5.50 \pm 2.429$ & $17.667 \pm 2.163$ & 0.001 & $9.167 \pm 2.994$ & 007 & .001 \\
\hline
\end{tabular}

Tabel 2. Tikus Non Alergi inhalasi OVA dengan ADT vs tanpa ADT (gingiva, PgLPS $1435 / 14503,0 \mu \mathrm{gg} / \mathrm{mL}$ )

\begin{tabular}{|c|c|c|c|c|c|c|}
\hline $\begin{array}{l}\text { Variabel } \\
\text { Tergantung }\end{array}$ & Pra-inhalasi & $\begin{array}{c}\text { inhalasi } \\
\text { Tanpa }\end{array}$ & & $\begin{array}{c}\text { inhalasi OVA } \\
\text { dengan ADT }\end{array}$ & & $\begin{array}{l}\text { Tanpa ADT vs } \\
\text { dengan ADT }\end{array}$ \\
\hline $\begin{array}{l}\text { Keradangan: } \\
\text { Imunogenik }\end{array}$ & Mean \pm SD & Mean \pm SD & $p$ & Mean \pm SD & $\mathbf{P}$ & $p$ \\
\hline $\begin{array}{l}\text { TNF- } a \\
\text { LTC4 } \\
\text { Neuogenic }\end{array}$ & $\begin{array}{c}34.833 \pm 2.483 \\
2.333 \pm 2.066\end{array}$ & $\begin{array}{c}29.50 \pm 2.429 \\
24.667 \pm 3.141\end{array}$ & $\begin{array}{l}.004 \\
.001\end{array}$ & $\begin{array}{l}26.333 \pm 2.805 \\
13.00 \pm 3.033\end{array}$ & $\begin{array}{l}.001 \\
.001\end{array}$ & $\begin{array}{l}.001 \\
.001\end{array}$ \\
\hline Substans P & $2.667 \pm 1.211$ & $21.50 \pm 2.588$ & .001 & $7.50 \pm 2.739$ & .003 & .001 \\
\hline
\end{tabular}

${ }^{*}$ perbedaan bermakna $(\mathrm{p}<0.05)$ 
Tabel 3. Tikus Alergi inhalasi OVA dengan ADT vs tanpa ADT (gingiva, $P g L P S_{1435 / 1450} 0.3 \mu \mathrm{g} / \mathrm{mL}$ )

\begin{tabular}{|c|c|c|c|c|c|c|}
\hline $\begin{array}{l}\text { Variabel } \\
\text { Tergantung }\end{array}$ & $\begin{array}{c}\text { Alergi } \\
\text { Pra-inhalasi }\end{array}$ & $\begin{array}{r}\text { Alergi inha } \\
\text { tanpa }\end{array}$ & DVA & $\begin{array}{r}\text { Alergi inhala } \\
\text { Dengan A }\end{array}$ & & $\begin{array}{c}\text { Tanpa ADT vs. } \\
\text { dengan ADT }\end{array}$ \\
\hline $\begin{array}{l}\text { Keradangan: } \\
\text { Imunogenik }\end{array}$ & Rerata \pm SD & Rerata \pm SD & $\mathbf{P}$ & Rerata \pm SD & $\mathbf{P}$ & $p$ \\
\hline $\begin{array}{l}\text { TNF-a } \\
\text { LTC4 } \\
\text { Neurogenik }\end{array}$ & $\begin{aligned} 20.167 & \pm 0.983 \\
4.333 & \pm 2.875\end{aligned}$ & $\begin{array}{c}21.167 \pm 1.169 \\
24.00 \pm 2.966\end{array}$ & $\begin{array}{l}.140^{*} \\
.001\end{array}$ & $\begin{array}{l}15.00 \pm 2.280 \\
10.833 \pm 1.722\end{array}$ & $\begin{array}{l}.001 \\
.001\end{array}$ & $\begin{array}{l}.001 \\
.001\end{array}$ \\
\hline Substans $P$ & $4.50 \pm 1.516$ & $24.00 \pm 3.742$ & .001 & $9.167 \pm 2.994$ & 007 & .001 \\
\hline
\end{tabular}

* perbedaan bermakna $(\mathrm{p}<0.05)$

Tabel 4. Tikus Alergi inhalasi OVA dengan ADT vs tanpa ADT (gingiva, PgLPS ${ }_{1435 / 1450} 3.0 \mu \mathrm{g} / \mathrm{mL}$ )

\begin{tabular}{lcccccc}
\hline $\begin{array}{l}\text { Variabel } \\
\text { Tergantung }\end{array}$ & Pra-inhalasi & $\begin{array}{c}\text { Inhalasi OVA } \\
\text { Tanpa ADT }\end{array}$ & $\begin{array}{c}\text { Inhalasi OVA } \\
\text { dengan ADT }\end{array}$ & $\begin{array}{c}\text { Tanpa ADT vs } \\
\text { dengan ADT }\end{array}$ \\
\hline $\begin{array}{l}\text { Keradangan: } \\
\text { Imunogenik }\end{array}$ & Rerata \pm SD & Rerata \pm SD & $\mathbf{P}$ & Rerata \pm SD & $\mathbf{P}$ & P \\
\cline { 2 - 7 } $\begin{array}{l}\text { TNF-a } \\
\text { LTC4 }\end{array}$ & $25.667 \pm 3.204$ & $21.333 \pm 1.862$ & .017 & $20.333 \pm 3.011$ & .014 & $.374^{*}$ \\
Neuogenic & $4.167 \pm 1.835$ & $23.833 \pm 2.787$ & .001 & $4.833 \pm 1.722$ & $.531^{*}$ & .001 \\
Substans P & $5.50 \pm 1.049$ & $23.833 \pm 2.787$ & .001 & $10.333 \pm 1.751$ & .001 & .001 \\
\hline
\end{tabular}

${ }^{*}$ perbedaan bermakna $(p<0.05)$

Tabel 5. Tikus Non Alergi inhalasi OVA dengan ADT vs tanpa ADT (hidung, $P g L P S_{1435 / 450} 0.3 \mu \mathrm{g} / \mathrm{mL}$ )

\begin{tabular}{lcccccc}
$\begin{array}{l}\text { Variabel } \\
\text { Tergantung }\end{array}$ & Pra-inhalasi & $\begin{array}{c}\text { Inhalasi OVA } \\
\text { Tanpa ADT }\end{array}$ & \multicolumn{2}{c}{$\begin{array}{c}\text { Inhalasi OVA } \\
\text { dengan ADT }\end{array}$} & $\begin{array}{c}\text { Tanpa ADT vs } \\
\text { dengan ADT }\end{array}$ \\
\hline $\begin{array}{l}\text { Keradangan } \\
\text { Imunogenik }\end{array}$ & Rerata \pm SD & Rerata \pm SD & $\mathbf{P}$ & Rerata \pm SD & $\mathbf{P}$ & $\mathbf{p}$ \\
\cline { 2 - 7 } $\begin{array}{l}\text { TNF-a } \\
\text { LTC4 }\end{array}$ & $20,667 \pm 1,862$ & $27,00 \pm 3,033$ & .001 & $10,333 \pm 1,966$ & .001 & .001 \\
$\begin{array}{l}\text { Neurogenik } \\
\text { Substans P }\end{array}$ & $5,833 \pm 2,041$ & $13,333 \pm 1,211$ & .001 & $4,167 \pm 1,472$ & $.234^{*}$ & .001 \\
& $6,667 \pm 2,733$ & $16,167 \pm 2,639$ & .001 & $4,167 \pm 2,137$ & $.259^{*}$ & .001
\end{tabular}

* perbedaan bermakna $(p<0.05)$

Tabel 6. Tikus Non Alergi inhalasi OVA dengan ADT vs tanpa ADT (hidung, $P g$ LPS $_{14351450} 3.0 \mu \mathrm{g} / \mathrm{mL}$ )

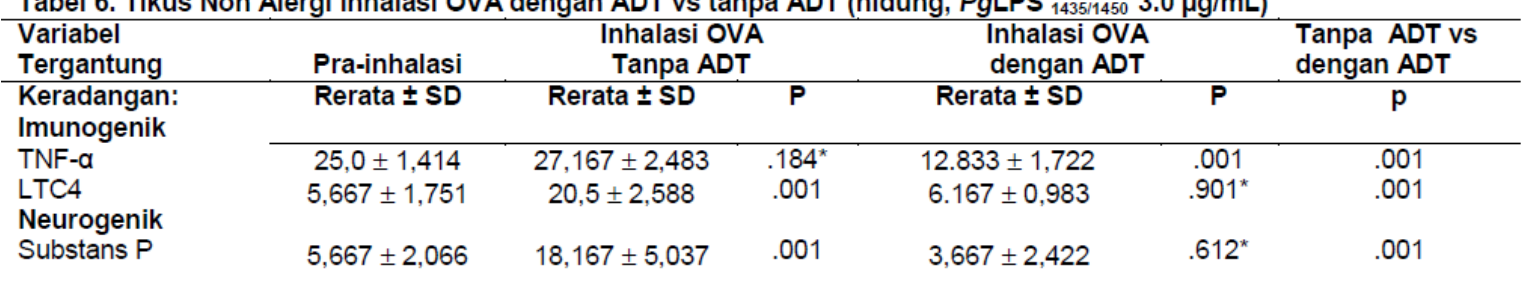

${ }^{*}$ perbedaan bermakna $(p<0.05)$

\begin{tabular}{|c|c|c|c|c|c|c|}
\hline \multirow{2}{*}{$\begin{array}{l}\text { Variabel } \\
\text { Tergantung } \\
\text { Keradangan: } \\
\text { Imunogenik } \\
\text { TNF-a } \\
\text { LTC4 } \\
\text { Neurogenik }\end{array}$} & \multirow{2}{*}{$\begin{array}{l}\text { Pra-inhalasi } \\
\text { Rerata } \pm \text { SD }\end{array}$} & \multicolumn{2}{|c|}{$\begin{array}{c}\text { Inhalasi OVA } \\
\text { Tanpa ADT }\end{array}$} & \multicolumn{2}{|c|}{$\begin{array}{c}\text { Inhalasi OVA } \\
\text { dengan ADT }\end{array}$} & \multirow{2}{*}{$\begin{array}{l}\text { Tanpa ADT vs } \\
\text { dengan ADT } \\
p\end{array}$} \\
\hline & & Rerata \pm SD & $\mathbf{P}$ & Rerata \pm SD & $\mathbf{P}$ & \\
\hline Substans $P$ & $14.333 \pm 3.327$ & $15.667 \pm 3.502$ & $.783^{\star}$ & $6.00 \pm 2.966$ & .002 & .001 \\
\hline
\end{tabular}

* perbedaan bermakna $(p<0.05)$

\begin{tabular}{|c|c|c|c|c|c|c|}
\hline \multirow{2}{*}{$\begin{array}{l}\text { Variabel } \\
\text { Tergantung } \\
\text { Keradangan: } \\
\text { Imunogenik }\end{array}$} & \multirow{2}{*}{$\begin{array}{c}\text { Pra-inhalasi } \\
\text { Mean } \pm \text { SD }\end{array}$} & \multicolumn{2}{|c|}{$\begin{array}{c}\text { Inhalasi OVA } \\
\text { Tanpa ADT }\end{array}$} & \multicolumn{2}{|c|}{$\begin{array}{l}\text { Inhalasi OVA } \\
\text { dengan ADT }\end{array}$} & \multirow{2}{*}{$\begin{array}{l}\text { Tanpa ADT vs } \\
\text { dengan ADT } \\
\mathbf{p}\end{array}$} \\
\hline & & Mean \pm SD & $\mathbf{p}$ & Mean \pm SD & $\mathbf{P}$ & \\
\hline $\begin{array}{l}\text { LTC4 } \\
\text { Neurogenik }\end{array}$ & $7.167 \pm 2.137$ & $22.00 \pm 1.414$ & .001 & $2.333 \pm 0.817$ & .001 & .001 \\
\hline Substans P & $15.833 \pm 3.061$ & $17.667 \pm 4.844$ & $.712^{\star}$ & $4.50 \pm 3.271$ & .001 & .001 \\
\hline
\end{tabular}

${ }^{\star}$ perbedaan bermakna $(p<0.05)$ 
Gingiva: $\quad$ injeksi PgLPS ${ }_{1435 / 1450} 0.3 \mu \mathrm{g} / \mathrm{mL}$
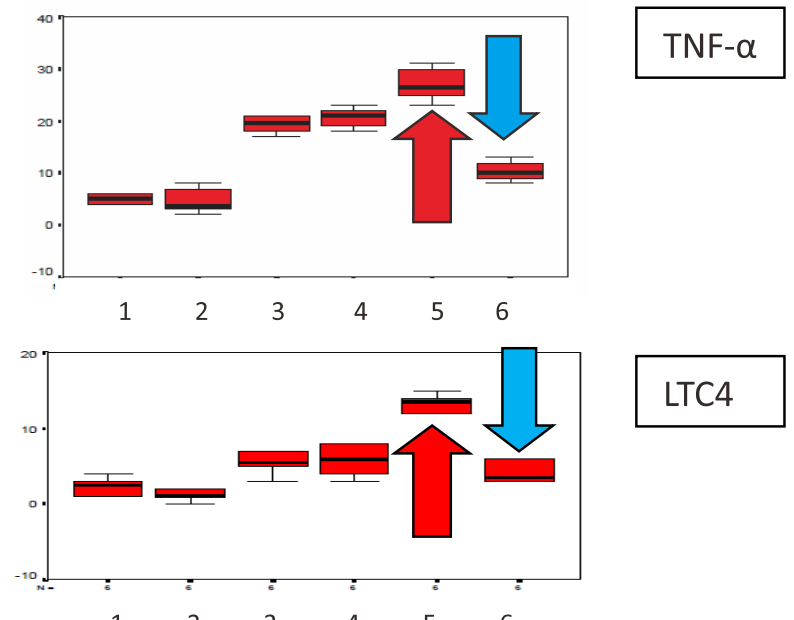

Hidung injeksi $P g \mathrm{LPS}_{1435 / 1450} \quad 0.3 \mu \mathrm{g} / \mathrm{mL}$
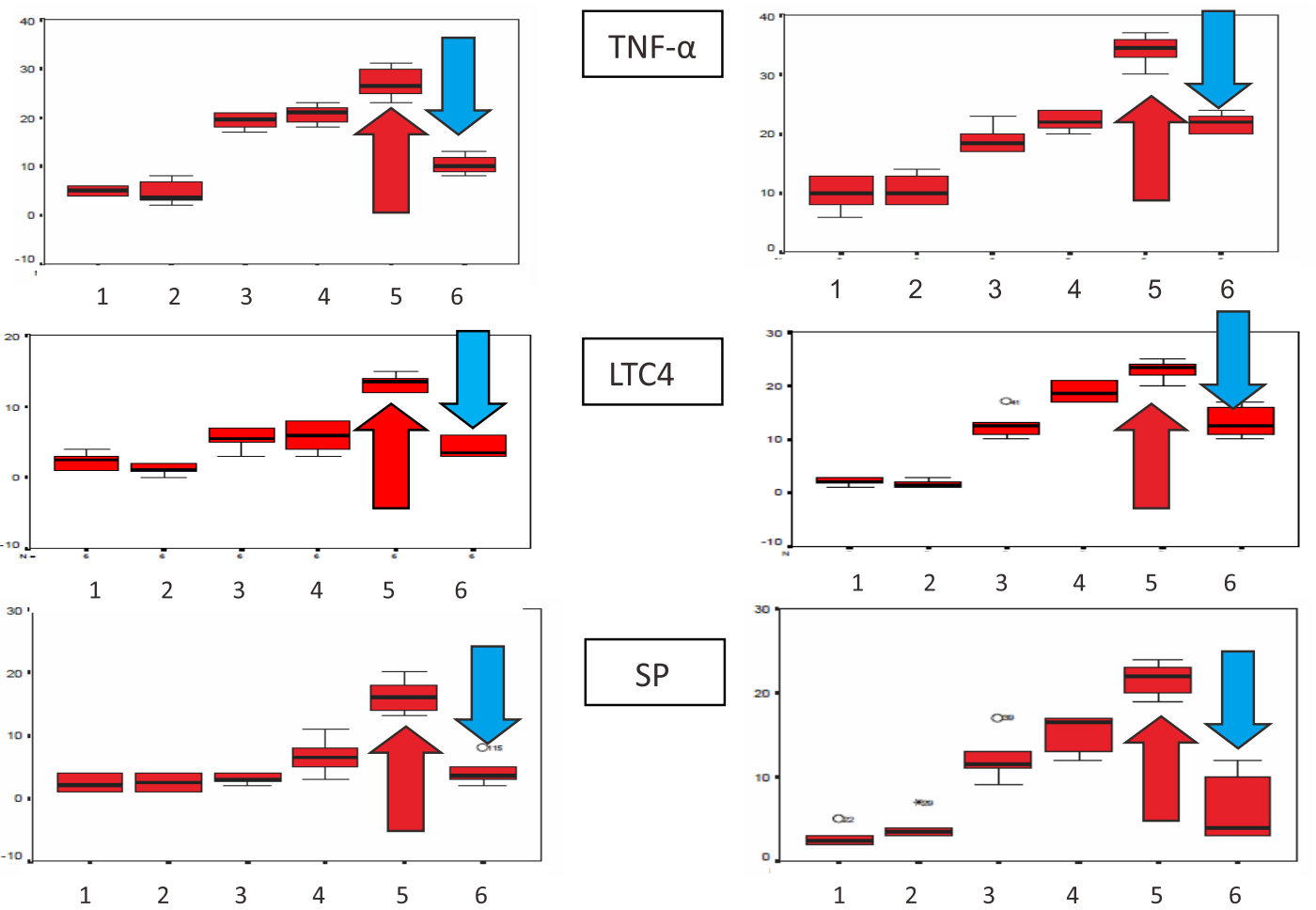

Gambar 6. Modulasi ekspresi biomarker migren TNF-a, LTC4 dan SP jaringan gingiva dan hidung

Catatan (1) kontrol (sebelum perlakuan); (2) setelah injeksi OVA hari ke 14: (3) setelah injeksi PgLPS 1435/1450 ke 2, sebelum injeksi OVA ke 2 hari ke 14; (4) prainhalasi OVA hari ke21); (5) inhalasi OVA (panah merah) tanpa ADT; (6) inhalasi OVA (panah merah) dengan ADT (panah biru)

\section{PEMBAHASAN}

Pengaruh infeksi rongga mulut yang juga disebut fokal infeksi ronggal mulut pada jaringan tubuh lain telah diperkirakan sejak ratusan bahkan ribuan tahun yang lalu. Akan tetapi, teori ini masih belum banyak dipercaya kalangan medis, apalagi setelah Dr. Weston Price pada tahun 1920an berteori bahwa gigi yang infeksi harus dicabut agar berbagai penyakit seperti radang sendi dapat sembuh. Karena tidak selalu berhasil padahal sudah banyak gigi yang dicabut maka pada tahun 1930an teori ini ditinggalkan. ${ }^{18}$

Lidkk ${ }^{18}$ dan Parahitiyawa dkk. ${ }^{19}$ mengumpulkan berbagai data pendukung hubungan fokal infeksi rongga mulut dengan penyakit sistemik, demikian pula dilakukan banyak peneliti yang lain sehingga makin terbukti pengaruh infeksi rongga mulut dengan penyakit serebrovaskuler, kardiovaskuler, Diabetes Mellitus type 2 dan lain-lain. Walaupun demikian, masih banyak fenomena dalam kasus praktek sehari-hari yang belum dapat dijelaskan dengan tuntas, misalnya penyebab alergi, sinusitis, asma, migren dan nyeri haid oleh infeksi gigi, yang dapat membaik setelah dilakukan perawatan

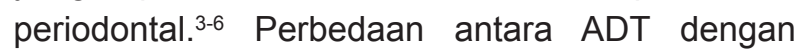
scaling dan perawatan periodontal konvensional adalah dapat mengurangi berbagai gejala penyakit tersebut dalam hitungan menit.

Berdasarkan penelitian ini didapatkan bahwa pada jaringan gingiva semua ekspresi biomarker migren kelompok non-alergi dan alergi setelah inhalasi OVA dengan ADT lebih rendah secara bermakna $(p=.001)$ daripada ekspresi pra-inhalasi, maupun inhalasi OVA tanpa ADT (Tabel 1-4) kecuali pada tikus non-alergi dengan PgLPS ${ }_{1435 / 1450} 0,3 \mu \mathrm{g} /$ $\mathrm{mL}$, ekspresi TNF- $\alpha$ dengan ADT lebih tinggi dari tanpa ADT (Tabel 1). Hal ini mungkin disebabkan karena ADT merupakan stimulan pada sulkus 
gingiva yang juga meningkatkan keradangan setempat, selain itu secara teoritis pada tikus alergi sitokin T-helper 2 antara lain IL-4 dan IL-13 bersifat antiinflamasi dan mengurangi aktifitas makrofag, salah satu penghasil TNF- $\alpha$, lebih banyak daripada tikus non-alergi sehingga mengurangi ekspresi TNF- $\alpha$ gingiva.

Pada jaringan hidung semua ekspresi biomarker migren kelompok non-alergi dan alergi setelah inhalasi OVA dengan ADT lebih rendah secara bermakna $(p=.001)$ daripada ekspresi prainhalasi, maupun inhalasi OVA tanpa ADT (Tabel 5-8). Hasil dari pemeriksaan jaringan gingiva dan hidung setelah ADT menunjukkan manfaat dari ADT sebagai imunomodulator pada kasus gingivitis dan migren karena dapat menurunkan ekspresi biomarker keradangan imunogenik dan neurogenik akibat stimulasi pencetus migren. Pada gambar boxplot (Gambar 6) lebih mudah terlihat perbedaan efek ADT yang menurunkan biomarker dibanding inhalasi OVA yang meningkatkan biomarker.

Penelitian Utomo dan Harsono ${ }^{6}$ menemukan bahwa setelah ADT pada anak asma alergi, kadar histamin serum sebelum dan dua jam setelah terapi berkurang secara bermakna. Karena histamin merupakan indikator aktifasi sel mast yang juga berperan dalam patogenesa migren sebagai inisiator keradangan neurogenik dan juga neurogenic switching, ${ }^{7,8}$ maka berkurangnya aktifasi sel mast berdasarkan penurunan ekspresi LTC4 setelah ADT pada tikus juga diperkirakan mempunyai efek klinis yang sama pada migren. Keluarnya darah secara pasif saat ADT juga berperan dalam drainase keluar mediator radang yang menimbulkan rangsangan impuls antidromik ke jaringan hidung dan jaringan lain yang terlibat dalam patogenesa migren.

Menurut Lundy dan Linden, ${ }^{8}$ LPS merupakan pemicu aktifasi sel imun melalui jalur TLR4 yang kemudian menyebabkan keradangan neurogenik. Keradangan neurogenik akan mengeluarkan neuropeptida antara lain SP dan calcitonin gene related peptide (CGRP) untuk mengeluarkan histamin dan triptase. Pada penelitian ini terbukti bahwa PgLPS $_{1435 / 1450}$ merupakan preparat yang dapat mengaktifasi sel mast berdasarkan peningkatan ekpresi LTC4 dan TNF- $\alpha$, serta aktifasi saraf aferen sensoris dengan peningkatan ekspresi SP (Gambar $6)$.

Mekanisme yang dapat menerangkan bagaimana ADT dengan cepat menurunkan biomarker migren antara lain karena terapi ini yang berupa masase selama tiga menit akan meningkatkan suhu jaringan sehingga terjadi penurunan $\mathrm{pH}$ jaringan dan peningkatan kadar $\mathrm{Ca}^{2+}$ ekstraseluler. Gangguan regulasi $\mathrm{Ca}^{2+}$ yang penting untuk presynaps menyebabkan kejadian synaptic plasticity selama beberapa menit sehingga menurunkan aliran impuls synaps. ${ }^{20}$ Impuls yang terputus ini menyebabkan ekspresi TNF- $\alpha$ dan SP, biomarker yang terlibat dalam neurogenic switching juga menurun dengan cepat.

Jawaban yang dianggap paling sesuai dari pertanyaan: "Mengapa gejala migren dapat berkurang dengan cepat?" adalah menghubungkan dengan waktu paruh (half life) suatu zat. Half life dari indikator alergi LTC4 adalah 7 menit, sehingga jarak waktu dari ADT sampai euthanasia yang \pm 60 menit sudah terjadi perubahan yang signifikan. Half life untuk komponen mekanisme neurogenic switching sangat cepat (TNF- $\alpha=17-30$ menit; SP $=<6$ menit). ${ }^{8}$ Berdasarkan data diatas sangat masuk akal karena ternyata ADT mempunyai efek "pemutus arus" pembangkit mekanisme neurogenic switching, karena efek peningkatan suhu maupun drainase dari mediator inflamasi yang keluar bersama darah saat dilakukan ADT.

Penelitian ini juga dapat menjelaskan mengapa pada penderita alergi faktor resiko migren 1,5 kali lebih besar. Peningkatan ekspresi LTC4 yang merupakan indikator aktifitas sel mast pada hidung, bila diperbandingkan antara non-alergi dan alergi, peningkatan ekspresi biomarker pada tikus alergi lebih besar. Pada perlakuan injeksi PgLPS $0.3 \mu \mathrm{g} /$ $\mathrm{mL}$, perbedaan ekspresi biomarker pra-inhalasi ke inhalasi OVA tikus non-alergi 5,833 $\pm 2,041$ menjadi 13,333 \pm 1.211 selisih \pm 7 (Tabel 5); ini lebih rendah bila dibandingkan dengan tikus alergi $7.167 \pm 0.753$ menjadi 19,167 $\pm 4,446$ yaitu \pm 15 (Tabel 7). Nonalergi $P g L P S ~ 3,0 \mu g / m L ~ 5,667 \pm 1.751$ menjadi 20,5 \pm 0.753 selisih \pm 12 (Tabel 6); sedangkan alergi 7,167 $\pm 2,137$ menjadi $22,00 \pm 1,414$ selisih \pm 14 (Tabel 8). 
Efek lokal ADT yang dapat terlihat secara klinis adalah keluarnya darah secara pasif pada jaringan gingivitis kronis karena masase dapat menyebabkan vasodilatasi pembuluh darah. Karena pada keradangan terjadi perubahan permeabilitas kapiler maka menyebabkan darah lebih mudah keluar. Walaupundarah keluar, padagingivitiskronis penderita tidak terasa nyeri. Evaluasi imunoneuromodulasi pada jaringan gingiva dan hidung menunjukkan efek menguntungkan dari ADT. Efek sistemik ADT yaitu dalam hitungan menit dibuktikan dengan penurunan biomarker jaringan hidung dengan evaluasi imunoneuromodulasi ekspresi TNF-a, LTC4 dan SP. Hal ini sangat mungkin disebabkan karena terhentinya mekanisme neurogenic switching akibat gangguan impuls presynaps selama beberapa menit sehingga jumlah neuropeptida berkurang, demikian pula aktifasi sel mast dan berbagai sel lain yang dapat distimulasi oleh neuropeptida terhenti. Penurunan aktiviitas sel mast akibat rangsangan LPS maupun neuropeptida setelah dilakukan ADT juga akan menurunkan reaksi alergi, sehingga kepekaan terhadap pemicu migrenpun berkurang.

\section{KESIMPULAN}

Terapi assisted drainage dapat menurunkan biomarker gejala migren dengan cepat karena masase pada sulkus gingiva dapat: (1) drainase mediator keradangan imunogenik dan neurogenik (2) mengurangi interaksi keradangan imunogenik dan neurogenik (neurogenic switching) akibat terjadi synaptic plasticity pada saraf aferen sensoris, sehingga menimbulkan fenomena "putus arus"; Berdasarkan hasil penelitian ini yang merupakan verifikasi evidence-based cases, ADT dapat diusulkan sebagai terapi ajuvan dalam tatalaksana migren. Akan tetapi, penelitian kolaborasi klinis dengan dokter ahli penyakit saraf, khususnya pakar nyeri orofasial sangat penting agar ADT dapat dimasukkan dalam tatalaksana migren.

\section{UCAPAN TERIMA KASIH}

Promotor dan ko-promotor Program Doktor Pasca Sarjana Universitas Airlangga: Prof. Dr. Dr. Subijanto Marto Sudarmo, SpA(KGE); Prof. Dr. drh. Fedik Abdul Rantam, DES. dan Prof.Dr. drg. M. Rubianto, SpPerio (K). Pembimbing dan konsultan penelitian hewan coba Prof. Dr. drh. Aulani'am, DES.

\section{DAFTAR PUSTAKA}

1. Czerwinski S, Gollero J, Qiu C,Sorensen TK, Williams MA. Migraine-asthma comorbidity and risk of hypertensive disorders of pregnancy. J Pregnancy. 2012; 1: 1-8.

2. Robbins L, Maides J. Headache: the Immune system and Headache. Practical Pain Management. 2011; 58-60.

3. Utomo H, Prahasanti C. Perawatan periodontal pada kasus nyeri kepala dan nyeri haid. Majalah CERIL. 2005; 14(4): 101-6.

4. Utomo H, Prahasanti C. Periodontal disease as an etiology of orofacial and musculoskeletal pains in women. Indonesian J Dentistry. 2006; 13(2): 202-5.

5. Utomo H, Pradopo S. Practical dental approach in children's rhinosinusitis management. Indonesian J Dent Dent. 2006; 13: 133-6.

6. Utomo H, Harsono A. Rapid improvement of respiratory quality in asthmatic children after the assisted drainage therapy. Pediatr Indones. 2010; 50(4): 199-207.

7. Meggs WJ. Neurogenic switching: a hypothesis for a mechanism for shifting the site of inflammation in allergy and chemical sensitivity. Environ Health Perspect. 1997; 105(2): 54-6.

8. Lundy W and Linden R. Neuropeptides and neurogenic mechanism in oral and periodontal inflammation. Crit Rev Oral Biol. 2004; 15(2): 82-98.

9. Assas BM, Miyan JA, Pennock JL. Crosstalk between neural and immune receptors provides a potential mechanism of homeostatic regulation in the gut mucosa. Mucosal Immunol. 2014; 7(6): 1283-9.

10. Theoharides TC. Migraine headaches: the immunologist's view. Hospital Chronicles. 2008; 3(4): 167-71. 
11. Ackerman S, Romero-Reyes M. Insights Into the pharmacological targeting of the trigeminocervical complex in the context of treatments of migraine. Expert Rev Neurother. 2013; 13(9): 1041-59.

12. Holmes AM, Solari R, Holgate ST. Animal models of asthma; value, limitations and opportunities for alternative purposes. Drug disc. 2012; 15: 659-70.

13. Al-Hashel JY, Ahmed SF, Alroughani R, Goadsby PJ. Migraine misdiagnosis as a sinusitis, a delay that can last for many years. J Headache and Pain. 2013; 14: 97-102.

14. Dumitrescu AL. Histological comparison of periodontal inflammatory changes in two models of experimental periodontitis in rat: a pilot study. TMJ. 2006; 56(2): 211-7.

15. Netea MG, van der Meer JWM, Sutmuller RP, Adema GJ, Kullberg BJ. From the Th1/Th2 paradigm towards a toll-like receptor/T-helper bias. Antimicrob Chemoth. 2005; 49(10): 3991-6.
16. Toward TJ, Broadley KJ. Early and late bronchoconstrictions, airway hyperreactivity, leucocyte influx and lung histamine and nitric oxide after inhaled antigen: effects of dexamethasone and rolipram. Clin Exp Allergy. 2004; 34: 91-102.

17. Newman MG,Takei HH, Klokkevold PR. Carranza's clinical periodontology. Ed 10. St Louis: Saunders-Elsevier: 2006. H. 105.

18. Li X, Kolltveit KM, Tronstad L, Olsen I. Systemic diseases caused by oral infection. Clin Microbiol Rev. 2000; 13(4): 547-58.

19. Parahitiyawa NB, Jin LJ, M Leung WK, Yam WC,L. P. Samaranayake LP. Microbiology of odontogenic bacteremia: beyond endocarditis. Clin Microbiol Rev. 2009; 22(1): 46-64.

20 Klose MK, Atwood HL, Robertson RM. Hyperthermic preconditioning of presynaptic Calcium regulation in Drosophila. JNeurophysiol. 2008; 99: 2420-30. 